\title{
Viceroy butterfly Limenitis archippus (Cramer) (Lepidoptera: Nymphalidae: Limenitidinae) ${ }^{1}$
}

\author{
Andrei Sourakov ${ }^{2}$
}

\section{Introduction}

A typical representative of the genus Limenitis Fabricius is a black butterfly with white vertical stripes down its wings (from which they get their common name of admirals). The genus is Holarctic, with majority of species found in the Far East.

Limenitis archippus is commonly known as "viceroy" because it is similar but smaller than a monarch butterfly. However, it is only distantly related to monarchs and other milkweed butterflies of the subfamily Danainae. The mimetic relationship between North American milkweed butterflies and the viceroy was shown to be Müllerian, meaning that both species are unpalatable and hence contribute to each others' protection from birds (Ritland 1991, Ritland \& Brower 1991).

\section{Synonymy}

Due to its unusual coloration caused by mimicry, L. archippus is sometimes placed in a separate genus Basilarchia Scudder (Smith et al. 1994). However, this placement is not supported by modern research on the genus (Mullen, 2006).

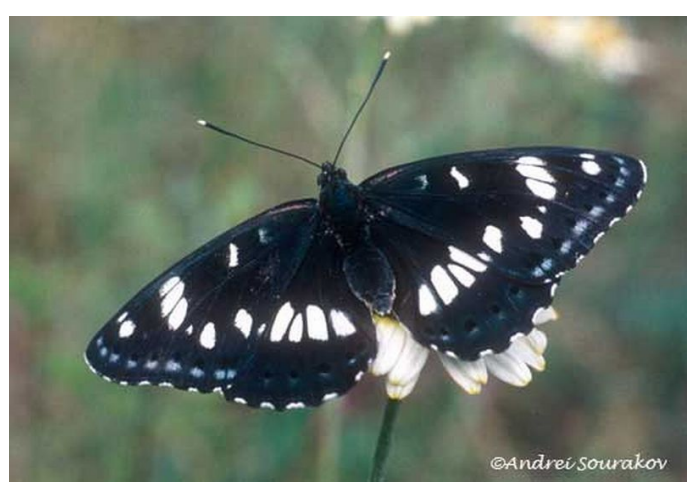

Figure 1. Dorsal view of an adult southern white admiral, Limenitis reducta Staudinger, a typical representative of the genus Limenitis. (Khosrov, Armenia.) Credits: Andrei Sourakov, Florida Museum of Natural History

Several synonyms have been described, among which are disippe, pseudodorippus, rubidus, and others. See the viceroy pages on the Butterflies of America Web site for a complete listing.

\section{Distribution}

The species is found east of the U.S. Cascade and Sierra Nevada mountain ranges to Central Mexico and Florida in the south with stray specimens found in Cuba (Opler, Lotts and Naberhaus 2009; Alayo and Hernandez 1987).

1. This document is EENY 458, one of a series of the Entomology and Nematology Department, Florida Cooperative Extension Service, Institute of Food and Agricultural Sciences, University of Florida. Original publication date June 2009. Visit the EDIS Web Site at http://edis.ifas.ufl.edu. 2. Andrei Sourakov, Florida Museum of Natural History

The Institute of Food and Agricultural Sciences (IFAS) is an Equal Opportunity Institution authorized to provide research, educational information and other services only to individuals and institutions that function with non-discrimination with respect to race, creed, color, religion, age, disability, sex, sexual orientation, marital status, national origin, political opinions or affiliations. U.S. Department of Agriculture, Cooperative Extension Service, University of Florida, IFAS, Florida A. \& M. University Cooperative Extension Program, and Boards of County Commissioners Cooperating. Millie Ferrer, Interim Dean 


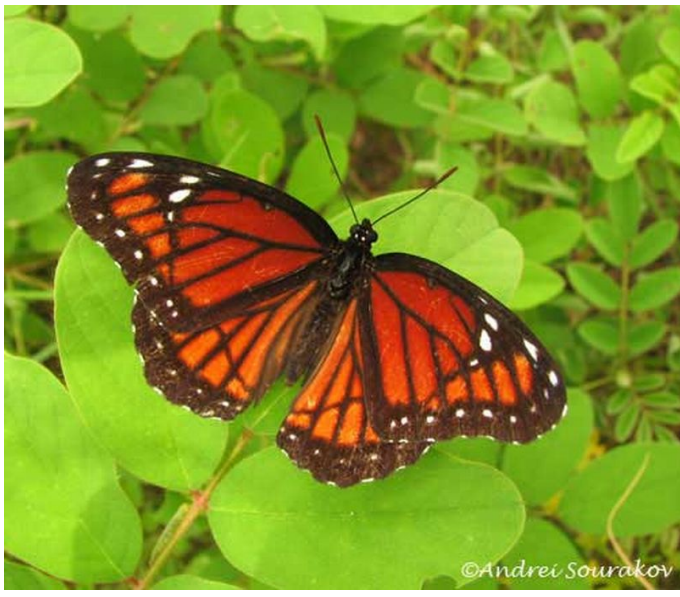

Figure 2. Dorsal view of the wings of an adult male viceroy, Limenitis archippus floridensis Strecker. (Natural Area Training Laboratory, University of Florida.) Credits: Andrei Sourakov, Florida Museum of Natural History

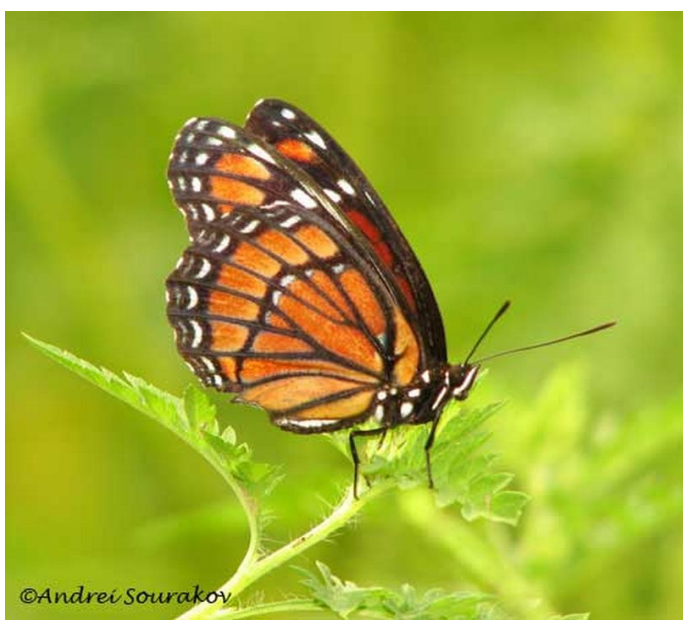

Figure 3. Ventral view of the wings of an adult male viceroy, Limenitis archippus floridensis Strecker. (Natural Area Training Laboratory, University of Florida.) Credits: Andrei Sourakov, Florida Museum of Natural History

There are seven described subspecies:

In addition to nominative $L$. a. archippus Cramer 1775, described from New York, which merges in Georgia with L. a. floridensis Strecker 1878, there are several other more local subspecies. Limenitis a. obsoleta Edwards 1882 flies in Utah and Arizona and is of conservation concern due to loss of habitat. Limenitis a. hoffmanni Chermock 1947 is found in Mexico; L. a. watsoni dos Pasos 1938 was described from Louisiana. Limenitis a. idaho Austin 1998 and L. a. lahontani Herlan, 1971, were the most recently described subspecies - both found exclusively in Nevada (Pelham 2008). Illustrations of all these subspecies can be found on the Butterflies of America Web site.

\section{Description}

The wing span of the adult ranges from $21 / 2$ to 3 $3 / 8$ inches $(6.3$ to $8.6 \mathrm{~cm})$. The viceroy is a very distinct butterfly for its genus, but can be confused with monarchs, queens, and soldiers, which it mimics in different parts of its range.

Viceroy forms occasional natural hybrids with the red spotted purple, Limenitis astyanax. Immature stages of the latter species are very similar to these of the viceroy.

\section{Life Cycle}

Adults: Adult viceroy populations form two to three broods per year throughout most of its range, though perhaps reproduction is continuous in south Florida. Adult viceroys prefer wet habitat along ponds, swamps, and rivers, where their host plants frequently line the banks. Males actively perch in the late morning and early afternoon, looking out for females and defending their territory.

Eggs: The eggs are laid singly on tips of leaves, resembling galls.

Larvae: The first instar larvae hatch roughly five days after oviposition and construct perches by feeding on a tip of the leaf, but leaving the central vein intact. The young larvae, when not feeding, usually occupy that tip of the central vein. First instar larvae have no protrusions.

The second instar larva has a saddle. If photoperiod is less than a given threshold, the third instar larva will diapause. It covers the stem of the leaf with silk all the way to the branch, hence securing it from falling off during winter. After consuming most of this leaf, a tube-like shelter is constructed.

In the spring, the hibernating larva starts feeding on fresh willow leaves and completes its development in approximately three weeks. Larvae are cryptically colored throughout and possess increasingly long protrusions of the thoracic segment.

Pupae: The pupae are also cryptically colored. 


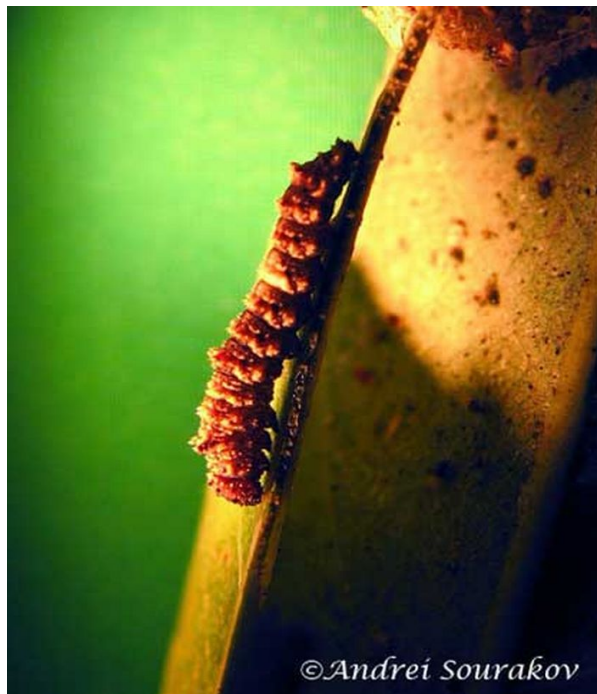

Figure 4. A 1st instar larva of the viceroy, Limenitis archippus floridensis Strecker. (Natural Area Training Laboratory, University of Florida.) Credits: Andrei Sourakov, Florida Museum of Natural History

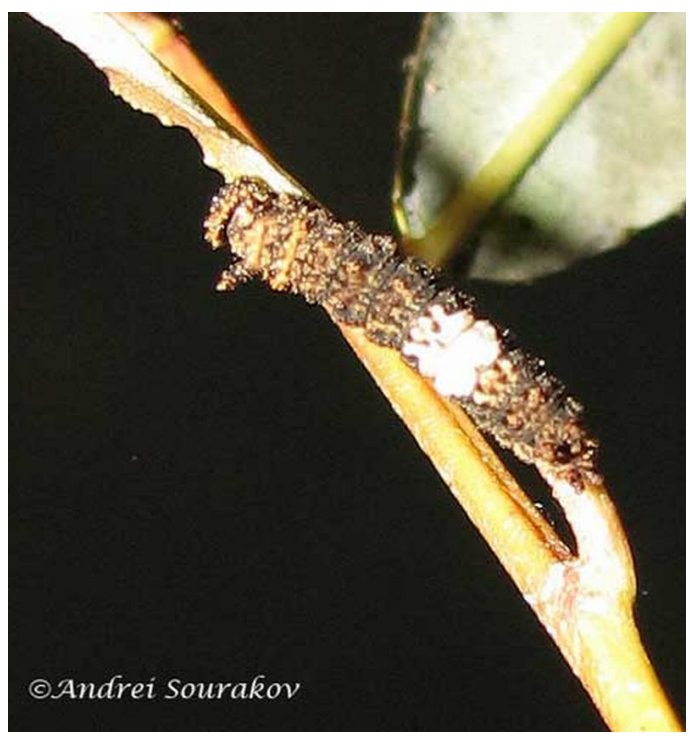

Figure 5. A perching 2nd instar larva of the viceroy, Limenitis archippus floridensis Strecker. (Natural Area Training Laboratory, University of Florida.) Credits: Andrei Sourakov, Florida Museum of Natural History

\section{Hosts}

Caterpillars feed on trees in the willow family (Salicaceae) including willows (Salix), and poplars and cottonwoods (Populus) (Opler, Lotts and Naberhaus 2009).

Adult viceroys feed on a variety of flowers, preferring composites, but also, typically of Limenitidinae, will feed on rotten fruit, carrion, and feces. They sequester salicylic acid from substances

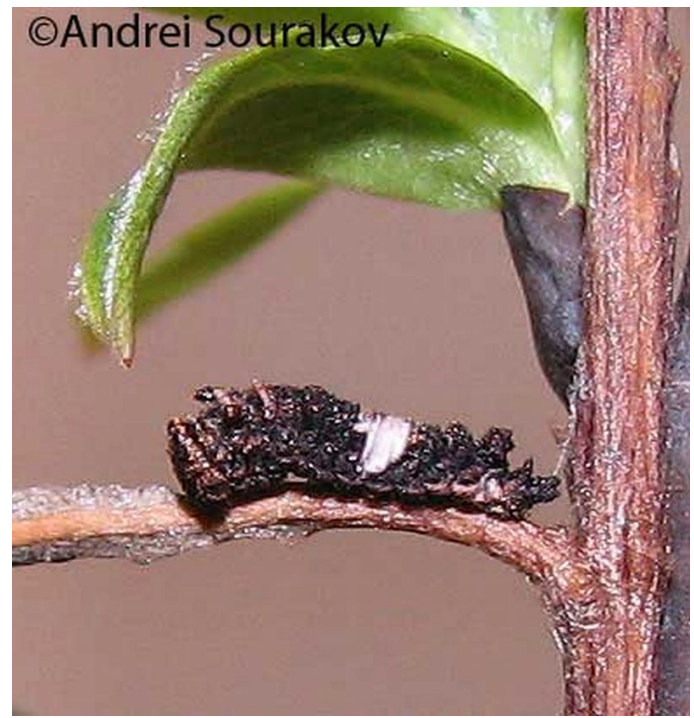

Figure 6. A 3rd instar larva of the viceroy, Limenitis archippus floridensis Strecker, after hibernation. (Natural Area Training Laboratory, University of Florida.) Credits: Andrei Sourakov, Florida Museum of Natural History

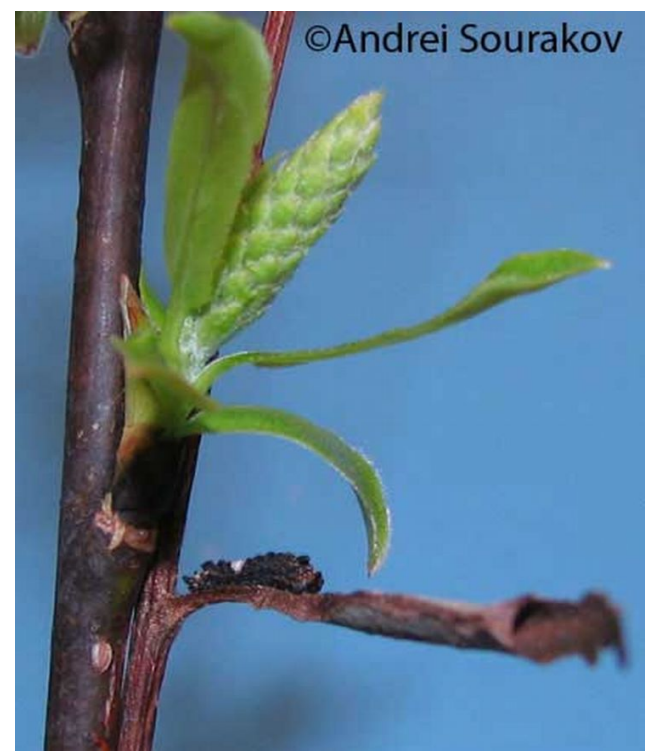

Figure 7. A 3rd instar larva of the viceroy, Limenitis archippus floridensis Strecker, after hibernation, sitting at the base of shelter in which it spent the winter. (Natural Area Training Laboratory, University of Florida.) Credits: Andrei Sourakov, Florida Museum of Natural History

ingested by the caterpillar from its host plant, which makes adults bitter to taste, hence its aposematic coloration and display behavior.

\section{Economic Importance}

Limenitis archippus is the Kentucky state butterfly. 


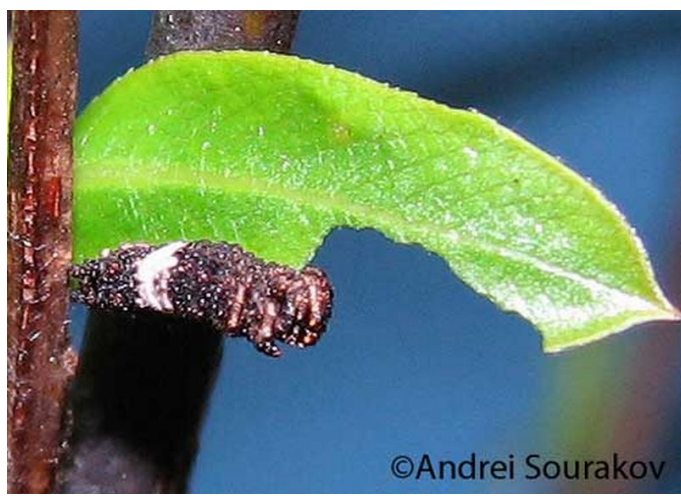

Figure 8. The 3rd instar larva of the viceroy, Limenitis archippus floridensis Strecker, starts feeding on fresh willow leaves in early spring following four months of hibernation. This specimen appears greatly desiccated. (Natural Area Training Laboratory, University of Florida.) Credits: Andrei Sourakov, Florida Museum of Natural History

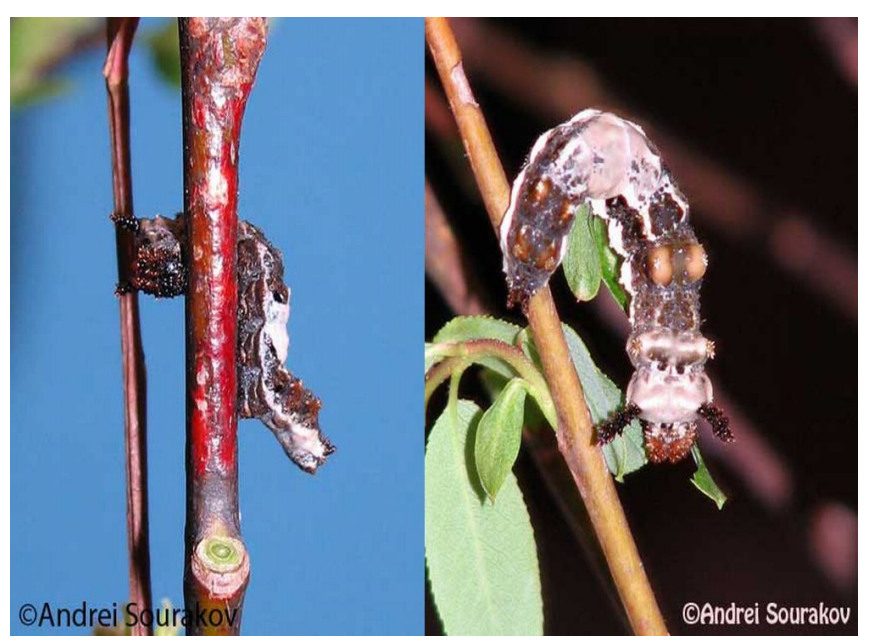

Figure 9. The 4th instar larva of the viceroy, Limenitis archippus floridensis Strecker, resembles a twig (left) or a bird dropping (right) depending on its position on the plant. (Natural Area Training Laboratory, University of Florida.) Credits: Andrei Sourakov, Florida Museum of Natural History

Because of the mimetic nature of viceroy's coloration and its ability to form hybrids with other North American Limenitis, the species received attention from biologists studying evolution and mimicry. For instance, a number of studies involving bird predation were conducted, using viceroys in conjunction with caged birds and other members of mimicry complex (Ritland 1991, Ritland and Brower 1991).

Due to the fact that viceroy populations were maintained in captivity, significant contributions to understanding photoperiodism and its role in

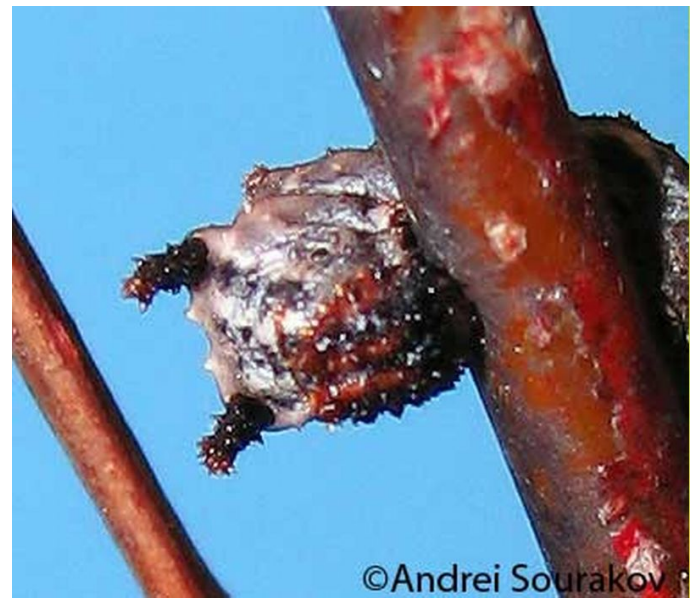

Figure 10. Head of the 4th instar larva of the viceroy, Limenitis archippus floridensis Strecker. (Natural Area Training Laboratory, University of Florida.) Credits: Andrei Sourakov, Florida Museum of Natural History

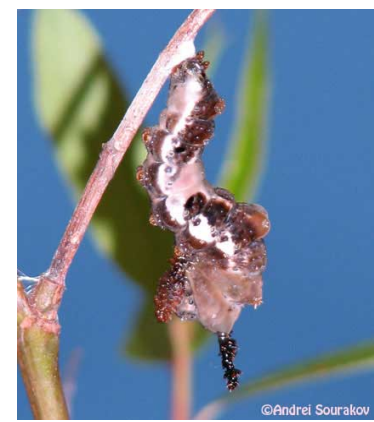

Figure 11. Prepupa of the viceroy, Limenitis archippus floridensis Strecker. (Natural Area Training Laboratory, University of Florida.) Credits: Andrei Sourakov, Florida Museum of Natural History

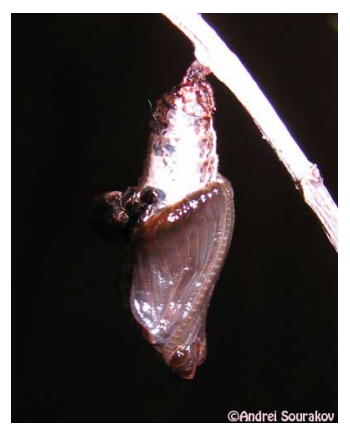

Figure 12. Pupa of the viceroy, Limenitis archippus floridensis Strecker. (Natural Area Training Laboratory, University of Florida.) Credits: Andrei Sourakov, Florida Museum of Natural History

triggering diapause in butterflies was achieved (Clark and Platt 1969, Hong and Platt 1975).

Perhaps the most important contribution of viceroys to general biology is in experimental interbreeding of mimetic and non-mimetic Limenitis, 
which showed how evolution of mimicry might have occurred (Platt 1975).

\section{Selected References}

- Alayo PD, Hernandez LR. 1987. Atlas de las mariposas diurnas de Cuba (Lepidoptera:

Rhopalocera). La Habana: Editorial

Cientifico-Tecnica.

- Opler, PA, Lotts K, Naberhaus T. (2009). Viceroy, Limenitis archippus (Cramer, 1776). Butterflies and Moths of North America. http://www.butterfliesandmoths.org/ species? $1=1788$ (17 June 2009).

- Clark SH, Platt AP. 1969. Influence of photoperiod on development and larval diapause in the viceroy butterfly, Limenitis archippus. Journal of Insect Physiology 15: 1951-1957.

- Hong JW, Platt AP. 1975. Critical photoperiod and daylength threshold differences between northern and southern populations of the butterfly Limenitis archippus. Journal of Insect Physiology 21: 1159-1165.

- Mullen, SP. 2006. Wing pattern evolution and the origins of mimicry among North American admiral butterflies (Nymphalidae: Limenitis). Molecular Phylogenetics and Evolution 39: 747-758.

- Pelham JP. 2008. A catalogue of the butterflies of the United States and Canada. Journal of Research on the Lepidoptera 40: 1-658.

- Platt AP. 1975. Monomorphic mimicry in nearctic Limenitis butterflies: experimental hybridization of the L. arthemis-astyanax complex with L. archippus source. Evolution 29: 120-141.

- Platt AP, Coppinger RP, Brower LP. 1971. Demonstration of the selective advantage of mimetic Limenitis butterflies presented to caged avian predators. Evolution 25: 692-701.

- Ritland DB. 1991. Revising a classic butterfly mimicry scenario: demonstration of Mullerian mimicry between Florida viceroys (Limenitis archippus floridensis) and queens (Danaus gilippus berenice). Evolution 45: 918-934.

- Ritland DB, Brower LP. 1991. The viceroy butterfly is not a batesian mimic. Nature 350 : 497-498. 